\title{
The Impact of After-sales Service Quality on Customer Satisfaction and Customer Loyalty of Middle-upper Class Landed Housings
}

\author{
Didik Wahjudi ${ }^{*}$,Timoticin Kwanda², Rianthi Sulis ${ }^{3}$
}

\begin{abstract}
Nowadays, good products are not sufficient. The market competition requires an excellent after-sales service. After-sales service quality has been identified as a source of revenue and competitive advantage. While other industry sectors have readily paid attention to aftersales service quality, little study has been done on the effectiveness of after-sales service quality in the field of landed housings. This study aims to explore the relationship among after-sales service quality, customer satisfaction, and customer loyalty. Especially, we want to confirm the impact of after-sales service quality on customer satisfaction and customer loyalty of middleupper class landed housings in Surabaya. This research was conducted by a survey on 170 respondents from four housing complexes in Surabaya, i.e. Pakuwon City, Citraland, Bukit Darmo Golf, and Graha Family. The data was examined by using structural equation modeling (SEM). Through data analysis, we confirm the positive correlation between after-sales service quality and customer satisfaction, the positive correlation between customer satisfaction and customer loyalty, and the direct and indirect relationships between after-sales service quality and customer loyalty. The practical implication of this study provides assurance to landed housing management on the effectiveness of after-sales service quality in maintaining old customers and encouraging new consumers.
\end{abstract}

Keywords: After-sales service quality; customer satisfaction; customer loyalty; middle-upper class landed housing.

\section{Introduction}

The importance of after-sales service quality has been widely recognized in all industry sectors, not only in pure service sectors but also in sectors where service is considered as a part of an augmented product (Rigopoulou et al. [1]). Furthermore, Rigopoulou et al. [1] identify the ever-increasing relative significance of the after-sales service quality to the core products/services as a part of differentiation strategy. Several studies claim the relationship between after-sales service quality, customer satisfaction, customer loyalty, and profitability (Anderson and Mittal [2]). Existing studies find a significant influence of after-sales service quality on customer satisfaction and customer loyalty. Customer loyalty occurs only when the customers are delighted with the products/services (Yang and Peterson [3]). Excellent after-sales service quality not only affects the retention of existing customers and but also increases the number of new customers (Anderson et al. [4]).

\footnotetext{
${ }^{1}$ Faculty of Industrial Technology, Mechanical Engineering Department, Petra Christian University, J. Siwalankerto 121-131, Surabaya 60236, INDONESIA. Email:dwahjudi@petra.ac.id

${ }^{2}$ Faculty of Civil Engineering and Planning, Architecture Department, Petra Christian University, Л. Siwalankerto 121-131, Surabaya 60236, INDONESIA. Email: cornelia@petra.ac.id

Email: cornelia@petra.ac.id

${ }^{3}$ Faculty of Civil Engineering and Planning, Civil Engineering Master Program, Petra Christian University, Jl. Siwalankerto 121-131, Surabaya 60236, INDONESIA. Email: rianthi.sulisthio@gmail.com

* Corresponding author
}

Satisfied customers are more likely to recommend the products/services to other customers, have greater repurchase intentions, and make actual repurchase action (Anderson and Mittal [2]).

The relationship among after-sales service quality, customer satisfaction, and customer loyalty has been widely confirmed through studies in many areas such as in the telecommunication industry, aviation services, automobile manufacturing, hospitality services, and health services. From each research, researchers find a relationship among after-sales service, customer satisfaction, and customer loyalty. However, little is known on the relationship among after-sales service quality, customer satisfaction, and customer loyalty in the area of real estate industry especially landed housing. This study aims to investigate whether the after-sales service quality also provides advantages as it is claimed in other industry sectors. In particular, this study wants to verify the relationship among after-sales service quality, customer satisfaction, and customer loyalty of middle- upper class landed housings' consumers in Surabaya, Indonesia. The middle-upper class segment was chosen because this market segment has the capability to make subsequent housing purchases so that the loyalty variable in this study becomes more relevant. The landed housing sector was selected to be the focus of this study because after-sales service quality in the landed housing was not much investigated compared to apartment housing. 


\section{Methods}

\section{After-sales Service Quality}

After-sales service is service that is provided to the customer after the product has been delivered (Rigopoulou et al. [1]). This service is intended to support customers in the use and disposal of the product (Fazlzadeh et al. [5]). After-sales service is a means to provide benefits to customers and create a business opportunity for the company (Saccani et al., [6]). After-sales service is generally utilized in a manufacturing industry. Manufacturing firms strive to meet customer needs with product design, comprehensive product offerings, consumer support, and after-sales service (Lele [7]). In the landed housing field, after-sales service can be in the form of (a) maintenance (the work required to keep or maintain a building at a good level), (b) alteration (development of facilities that makes the building more suitable for today's use, (c) conversion (provision of new facilities or re-arrangement of internal space for the compatibility of new uses).

Parasuraman et al. [8] identify five dimensions of service quality, i.e. tangible, reliability, responsiveness, assurance, and empathy. Tangible is about the outlook of physical facilities, equipment, staff, and communication materials. Reliability represents the capacity to fulfill stated service responsibly and faithfully. Responsiveness describes the readiness of staff to assist customers and offer reliable service. Assurance measures the competence and politeness of staff and the capability to create trust and confidence. Empathy indicates an attentive and personalized concern to customers. This study adopted constructs proposed by Parasuraman et al. [8] to measure the five dimensions of after-sales service quality.

\section{Customer Satisfaction}

Existing studies identify two concepts of customer satisfaction, i.e. transaction-specific customer satisfaction and cumulative customer satisfaction. Transaction-specific customer satisfaction refers to an evaluation over a specific purchase transaction, while cumulative customer satisfaction represents evaluation based on the total purchase and usage of goods or services over time (Anderson et al. [4]). This study adopted the cumulative customer satisfaction because it aimed to measure the overall satisfaction of customers over a quite long time period.

Many studies utilize the single scale to measure satisfaction using scale 1 to 5 or 1 to 7 , where $1=$ very dissatisfied and 5 or $7=$ very satisfied. However, this simple measurement does not represent the com-plexity of customer of satisfaction because customer satisfaction is behavior and emotion that cannot be measured directly (Fornell et al. [9]). This study adopted five-scale construct proposed by Fornell et al. [9] appended by two items from Gorondutse and Hilman [10] and Ndubisi and Wah [11] to measure customer satisfaction.

\section{Customer Loyalty}

Customer loyalty has been identified as the prominent source of competitive advantage (Khan [12], Lin and Wang [13]). The literature identifies different kinds of customer loyalty. At first customer loyalty is assumed to comprise of behavioral loyalty only (Rauyruen et al. [14]). Behavioral loyalty is defined as readiness to make a repeat purchase from or maintain an association with a company (Khan [12]). Later on, some authors come with the idea of attitudinal loyalty, which is described as emotional attachment to the company, provision of positive word of mouth, and recommendation to use its product/service (Khan, [12], Rauyruen et al.[14]. Gremler and Brown [15] propose another kind of loyalty, cognitive loyalty. Cognitive loyalty is characterized as considering no other alternatives when there is a need to make a decision as to what or where to buy product/service (Gremler and Brown [15]). Rauyruen et al. [14] recommend the use of composite loyalty that combines behavioral and attitudinal loyalty. They argue that when a purchase decision is made it is difficult to distinguish whether that decision is supported by behavioral or attitudinal loyalty. This study adopted the concept of composite loyalty proposed by Rauyruen et al. [14]. The customer loyalty construct was operationalized as willingness to recommend product/service of the company (Gorondutse and Hilman [10]), considering to purchase product/service from the company as the first choice (Gorondutse and Hilman [10]), price tolerance (Gorondutse and Hilman [10]), desire to build a long-term relationship with the company (Gorondutse and Hilman [10]), willingness to provide feedback to the company (Gorondutse and Hilman [10]), pride of the product's premium or prestigious value (Rauyruen et al. [14]).

\section{Development of Theoretical Framework}

The relationship between service quality and customer satisfaction has been widely discussed in the literature. Excellent quality service is argued to improve customer retention and increase new customer growth (Ahn and Sohn [16]). In addition, firms can obtain useful information about customer needs through after-sales service, which in turn will result in higher customer satisfaction. Links between after-sales service quality and customer satisfaction are identified by several authors through empirical studies (Ahn and Sohn [16], Gorondutse and Hilman, [10], Rigopoulou et al. [1]). 


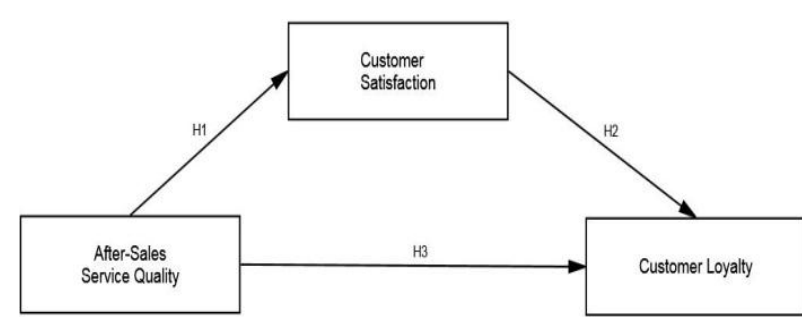

Figure 1. The conceptual framework

Customer satisfaction is identified to be one key factor that affects customer loyalty (Gorondutse and Hilman [10], Khan [12], Lin and Wang [13], Rauyruen et al. [14] Aktepe et al. [17]). Loyalty level can be measured through the length of the relationship between producer and customer. The more satisfied is the customer, the longer the relationship will be. Aktepe et al. [17] identify very satisfied customers are the best customer group and a targeted customer group because they share their satisfaction with other customers.

After-sales service quality is reported to have a strong influence on customer loyalty, either directly or indirectly through customer satisfaction. Zeithaml et al. [17] identify the direct and indirect links between service quality and customer loyalty, while Gorondutse and Hilman [10] and Parasuraman et al. [8] only find the indirect impact of service quality on customer loyalty through customer satisfaction. They do not find a significant direct link between service quality and customer loyalty.

Based on the above discussion, we developed the following hypotheses:

$\mathrm{H}_{1}$ : After-sales service quality is positively correlated with customer satisfaction of middle-upper class landed housing companies in Surabaya.

$\mathrm{H}_{2}$ : Customer satisfaction is positively correlated with customer loyalty of middle-upper class landed housing companies in Surabaya.

$\mathrm{H}_{3}$ : After-sales service quality is positively correlated with customer loyalty of middle-upper class landed housing companies in Surabaya.

Thus, the conceptual framework of this study is presented in Figure 1.

\section{Sample and Procedures}

The target population of this research was residents of middle-upper class housing complexes in Surabaya. These houses were built on a plot of land of 200-600 $\mathrm{m}^{2}$ and 600-2000 $\mathrm{m}^{2}$, with supporting operational facilities and infrastructure such as sports centers, parks, playgrounds, conference buildings, shopping centers, and even recreational facilities. The four middle-upper class housing complex surveyed were Pakuwon City, Citraland, Bukit Darmo Golf, and Graha Family. We utilized convenience sampling method to obtain responses because we did not have access to every resident of those complexes.

One hundred seventy respondents participated in the survey by completing the questionnaires. These respondents were asked to complete 34 indicators of the seven constructs using a five-point Likert scale, where $1=$ strongly disagree and $5=$ strongly agree. Five constructs were part of after-sales service quality, and one construct each for customer satisfaction and customer loyalty.

\section{Results and Discussions}

Table 1 provides the demography of respondents. Based on the respondents' demographic data, it was found that the largest portion of respondents was from Pakuwon City (East Surabaya) and Citraland (West Surabaya) housing complexes, with the largest age group was 30-44 years, and the largest ownership status was self-owned property. There were some respondents that owned houses smaller than $200 \mathrm{~m}^{2}$ in land area, but we still included them in our analysis because they enjoyed the same facilities and services with the remaining respondents.

Prior to the analysis, we conducted data screening as recommended by Hair et al. [19]. Data screening using SPSS software revealed no missing data. Next, data were examined for the existence of univariate and multivariate outliers. For detection of univariate outliers, cases that have $|\mathrm{z}|$ value greater than 4.0 were considered outliers (Hair et al. [19]). We found no case that had $|z|$ value greater than 4.0 , so all cases were retained. Multivariate outliers were identified using Mahalanobis distance (D2) divided by the number of variables. A conservative $p$-value of 0.001 recommended by Hair et al. [19] was used to identify multivariate outlier cases. This assessment detected 3 cases (\#64, 78, and 139) to be multivariate outliers and they were excluded from further analysis.

We followed two-step approach recommended by Anderson and Gerbing [20] to analyze the model in this study. First, measurement models were developed for all variables, i.e. tangibles, reliability, responsiveness, assurance, empathy, customer satisfaction, and customer loyalty. Then, a structural model that consisted of after-sales service quality, customer satisfaction, and customer loyalty was developed and examined to determine the relationship between them. 
Table 1. Demography of respondents

\begin{tabular}{|c|c|c|c|c|c|}
\hline & Frequency & Percentage & & Frequency & Percentage \\
\hline Gender & & & Occupation & & \\
\hline Male & 89 & $52.4 \%$ & Unemployed & 7 & $4.1 \%$ \\
\hline \multirow[t]{2}{*}{ Female } & 81 & $47.6 \%$ & Entrepreneurs & 88 & $51.8 \%$ \\
\hline & & & Employees & 44 & $25.9 \%$ \\
\hline Age & & & Civil servants, & 2 & $1.2 \%$ \\
\hline $18-29$ years & 38 & $22.4 \%$ & military, policemen & & \\
\hline $30-44$ years & 81 & $47.6 \%$ & Housewives & 25 & $14.7 \%$ \\
\hline $45-59$ years & 44 & $25.9 \%$ & Retired & 4 & $2.4 \%$ \\
\hline 60 years \& above & 7 & $4.1 \%$ & & & \\
\hline Housing complex & & & Land area & & \\
\hline Pakuwon City & 52 & $30.6 \%$ & Less than $200 \mathrm{~m}^{2}$ & 15 & $8.8 \%$ \\
\hline Citraland & 46 & $27.1 \%$ & 200 to $600 \mathrm{~m}^{2}$ & 99 & $58.2 \%$ \\
\hline Bukit Darmo Golf & 44 & $25.9 \%$ & 601 to $1000 \mathrm{~m}^{2}$ & 44 & $25.9 \%$ \\
\hline Graha Family & 28 & $16.5 \%$ & 1001 to $2000 \mathrm{~m}^{2}$ & 12 & $7.1 \%$ \\
\hline Ownership & & & Residency duration & & \\
\hline Self-owned & 100 & $58.8 \%$ & Less than 1 year & 21 & $12.4 \%$ \\
\hline Family-owned & 63 & $37.1 \%$ & 1 to 3 years & 53 & $31.2 \%$ \\
\hline Company-owned & 2 & $1.2 \%$ & 4 to 5 years & 39 & $22.9 \%$ \\
\hline Rented & 5 & $2.9 \%$ & More than 5 years & 57 & $33.5 \%$ \\
\hline
\end{tabular}

\section{Measurement Model}

Out of six indicators of the initial tangible dimension of after-sales service quality, only three of them were retained. Indicators $\tan 1$, $\tan 2$, and $\tan 6$ were removed because of low factor loadings, $0.35,0.25$, and 0.23 , respectively. These three indicators, namely developer maintains residential road very well ( $\tan 1)$, developer maintains cleanliness, picks up, and manages waste properly $(\tan 2)$, and developer maintains residential facilities such as clubhouse and sports areas regularly (tan6), may be considered as basic services so that they only have weak influence on the overall after-sales service quality assessment by the housing residents. The remaining items are shown in Table 2. All models showed good fit satisfying measures recommended by Hair et al. [19], i.e. models with number of observed variables less than 12 and number of observations of less than 250 to have CMIN/DF $\leq 3$, $\mathrm{CFI} \geq 0.97$, RMSEA $\leq 0.08$, and $\mathrm{SRMR} \leq 0.08$.

We developed three measurement models (i.e. aftersales service quality, customer satisfaction, customer loyalty) in the confirmatory factor analysis (CFA). The five dimensions of after-sales service quality were reduced into a construct of after-sales service quality through the CFA. This process aimed to reduce the number of variables to a manageable number while maintaining the characteristics of the original variables (Hair et al. [19]). The hypotheses were verified by using composite scores in the structural model. The use of composite score is considered to be superior to the summated scale because composite scores represent all variable loading on the factor (Hair et al. [19]).

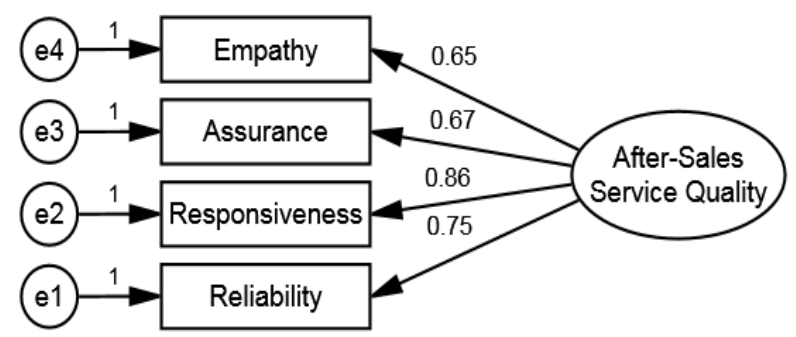

Figure 2. The second-order measurement model of ASSQ

After-sales service quality (ASSQ) had initially five 5 dimensions, namely tangible, reliability, responsiveness, assurance and empathy. However, during the data reduction, it was found that tangible had a small factor loading (0.32) on ASSQ. The small value of factor loading of tangible dimension in this study was possibly due to it was no longer a performance factor, but it had become a basic factor (Anderson and Mittal, [2]). In other words, tangible dimension did not make any difference in these middle-upper class landed housings because the four landed housing management had taken care of this tangible dimension. However, it would cause dissatisfaction if it did not exist (Wang and Ji [21]). Tangible dimension is also found to have small value by Berry et al. [22]. In that study, Berry et al. [22] ask 1900 respondents regarding the quality of after-sales service of 5 leading companies in America. They find that out of 5 dimensions of ASSQ, tangible has the smallest contri-bution, i.e. only $11 \%$. Thus, tangible was not included in the second-order measurement model of ASSQ, that is presented in Figure 2. The model fit of the second-order measurement model satisfied the model fit measures recommended by Hair et al. [19]. However, the reliability was a little bit below the recommended value of 0.7 . 
Table 2. Scale validity and reliability of five dimensions of ASSQ, customer satisfaction, and customer loyalty

\begin{tabular}{|c|c|c|c|c|}
\hline Scales & Item & & Loading & Cronbach's a \\
\hline \multirow[t]{3}{*}{ Tangible } & $\tan 3$ & The developer owns and implements good security system. & 0.51 & 0.643 \\
\hline & $\tan 4$ & The developer patrols and maintain security adequately. & 0.97 & \\
\hline & $\tan 5$ & The developer takes cares of plants in the housing complex well. & 0.42 & \\
\hline \multirow[t]{5}{*}{ Reliability } & rel1 & The developer performs maintenance and repair on schedule. & 0.60 & 0.819 \\
\hline & rel2 & The developer performs maintenance and repairs according to the promise. & 0.72 & \\
\hline & rel3 & $\begin{array}{l}\text { The developer performs maintenance and repair tasks according to the } \\
\text { deadline. }\end{array}$ & 0.75 & \\
\hline & rel4 & The developer responds to your problem sympathetically and swiftly. & 0.76 & \\
\hline & rel5 & The developer is reliable when a maintenance and repair problem arises. & 0.69 & \\
\hline \multirow[t]{5}{*}{$\begin{array}{l}\text { Responsi- } \\
\text { veness }\end{array}$} & res1 & $\begin{array}{l}\text { The developer clearly communicates the types of services and the procedures } \\
\text { before carrying out them. }\end{array}$ & 0.47 & 0.881 \\
\hline & res2 & The developer provides services quickly. & 0.64 & \\
\hline & res3 & The developer responds to your complaint quickly. & 0.78 & \\
\hline & res4 & $\begin{array}{l}\text { The developer handles damage claims in accordance with the promised } \\
\text { warranty easily and quickly. }\end{array}$ & 0.86 & \\
\hline & res5 & The developer's staff s are always willing to help your problem quickly. & 0.78 & \\
\hline \multirow[t]{4}{*}{ Assurance } & ass1 & The developer's service performance is convincing. & 0.78 & 0.796 \\
\hline & ass2 & The developer's staffs have good knowledge to answer your questions well. & 0.72 & \\
\hline & ass 3 & The developer's staffs are courteous in performing their duties. & 0.65 & \\
\hline & ass 4 & $\begin{array}{l}\text { You feel secure doing transactions or work contracts (maintenance and repair } \\
\text { of your house) with the developer's staffs. }\end{array}$ & 0.67 & \\
\hline \multirow[t]{4}{*}{ Empathy } & ept1 & $\begin{array}{l}\text { The developer provides personal attention to the maintenance and } \\
\text { improvement of your housing. }\end{array}$ & 0.46 & 0.742 \\
\hline & ept2 & The developer shows a sincere attitude to help your problem. & 0.49 & \\
\hline & ept3 & The developer provides flexible operations hours for you. & 0.65 & \\
\hline & ept4 & The developer's staffs understand what you need. & 0.93 & \\
\hline \multirow[t]{4}{*}{$\begin{array}{l}\text { Customer } \\
\text { satisfaction }\end{array}$} & sat1 & $\begin{array}{l}\text { You feel your developer is successfully meeting your housing maintenance } \\
\text { and repair needs. }\end{array}$ & 0.80 & 0.880 \\
\hline & sat2 & $\begin{array}{l}\text { You feel the quality of housing and services provided match the amount of } \\
\text { money you pay. }\end{array}$ & 0.69 & \\
\hline & sat3 & $\begin{array}{l}\text { You are happy with the after-sales service provided by your developer because } \\
\text { it has met your expectations. }\end{array}$ & 0.84 & \\
\hline & sat4 & $\begin{array}{l}\text { You are overall satisfied with the quality of housing and services provided by } \\
\text { the developer. }\end{array}$ & 0.90 & \\
\hline \multirow{6}{*}{$\begin{array}{l}\text { Customer } \\
\text { loyalty }\end{array}$} & loy1 & You will gladly recommend this housing developer to others to buy a house. & 0.69 & 0.836 \\
\hline & loy2 & $\begin{array}{l}\text { You consider to buy the product offered by the same developer as the first } \\
\text { choice. }\end{array}$ & 0.71 & \\
\hline & loy3 & $\begin{array}{l}\text { You are willing to keep on buying even though the developer's price is higher } \\
\text { than other developers. }\end{array}$ & 0.79 & \\
\hline & $\operatorname{loy} 4$ & You feel proud of your housing's premium / prestigious value. & 0.58 & \\
\hline & loy5 & You want to build a long-term relationship with the developer. & 0.75 & \\
\hline & $\operatorname{loy} 6$ & $\begin{array}{l}\text { You will be happy to provide suggestions or feedback to your developer if } \\
\text { requested. }\end{array}$ & 0.65 & \\
\hline
\end{tabular}

The Cronbach's alpha of this second-order measurement model was 0.632 .

\section{Structural Model}

Following the completion of measurement models, a path diagram was developed to examine the mediating effect of customer satisfaction on the relationship between ASSQ and customer loyalty. There were five control variables that we tested in our structural model, i.e. age, occupation, housing complex, ownership, and residency duration. However, none of them exhibited significant effects on customer loyalty. Hence, we did not include these control variables in the final model. The model fit indicated satisfactory results satisfying the model fit measures recommended by Hair et al. [19]. The path diagram of all variables is presented in Figure 3. ASSQ was positively correlated with customer satisfaction with standardized regression weight $(\beta)=0.903$ and $p<$ 0.001. Customer satisfaction was also positively correlated with customer loyalty with standardized regression weight $(\beta)=0.694$ and $p<0.001$. In the presence of customer satisfaction, the direct effect of ASSQ on customer loyalty was significant $(\beta=0.304$ and $p=0.001)$. Thus, all hypotheses $\left(\mathrm{H}_{1}, \mathrm{H}_{2}\right.$, and $\left.\mathrm{H}_{3}\right)$ were confirmed. The indirect effects of ASSQ on customer loyalty through customer satisfaction was significant with standardized regression weight $(\beta)=$ 0.224 and $p=0.05$. It can be inferred that the effects of ASSQ on customer loyalty was partially mediated by customer satisfaction. 


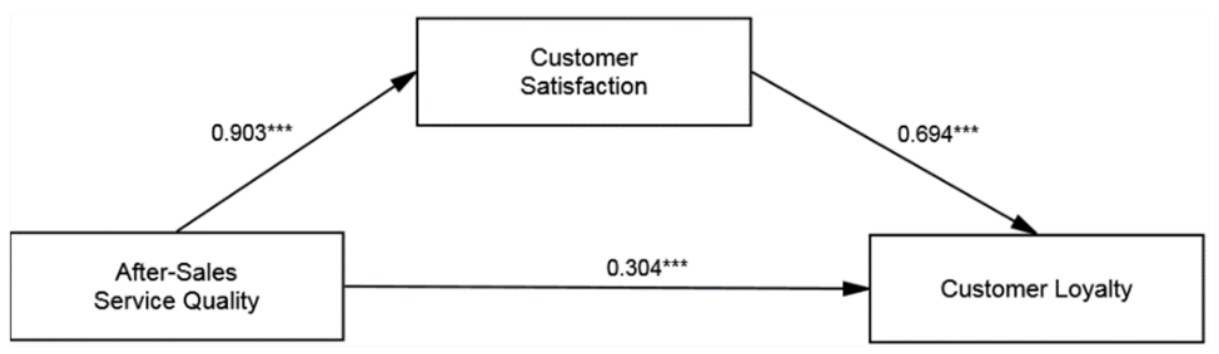

Figure 3. Path diagram of all variables

Table 1. Table of Effect Estimates and their $p$-values

\begin{tabular}{lccccc}
\hline \multicolumn{1}{c}{ Relationship } & Direct effect & $\mathrm{p}$ & Indirect effect & $\mathrm{p}$ & Comment \\
\hline ASSQ - Customer Satisfaction & 0.903 & $<0.001$ & - & - & \\
Customer Satisfaction - Customer Loyalty & 0.694 & $<0.001$ & - & - & \\
ASSQ - Customer Loyalty & 0.304 & $<0.001$ & 0.224 & 0.05 & Partial mediation \\
\hline
\end{tabular}

\section{Discussion of Findings}

This study aims to explore the relationships among after-sales service quality (ASSQ), customer satisfaction, and customer loyalty. To the best of our knowledge, this is the first study that explores the relationship between after-sales service quality and customer loyalty in the real estate field. There are three main findings from this study. First, the results of this study indicate that after-sales service quality is positively correlated with customer satisfaction of middle-upper class landed housing companies. This result is in line with the finding of Rigopoulou et al. [1], which confirms that ASSQ influences the value perceived by customers of electrical appliances. This finding also confirms the finding of Fazlzadeh et al. [5] that argues customer satisfaction is strongly influenced by the after-sales service quality. Second, this study identifies that customer satisfaction has positive impacts on consumer loyalty of middle-upper class landed housing companies. This finding supports the claim of several authors such as Bodet [23], Gorondutse and Hilman [10], Khan [12], Lin and Wang [13], and Rauyruen et al. [14] that there is a positive relationship between customer satisfaction and customer loyalty. Third, the finding of this study confirms the relationship between after-sales service quality and customer loyalty, both directly and indirectly through customer satisfaction. This result is also in accordance with previous research conducted by Zeithaml et al. [18] that identify the evidence of relationship among after-sales service quality, customer satisfaction, and customer attitude. Customers that do not have service issues have the strongest level of loyalty. However, Gorondutse and Hilman [10] and Parasuraman et al. [8] claim that the impact of after-sales service quality on customer loyalty can only be accomplished through customer satisfaction. In other words, they argue that there is no direct link between after-sales service quality and customer loyalty.

\section{Conclusion}

There are limited studies on service quality in real estate field especially on landed housings, unlike in the manufacturing field. Through this study, some relationships that are identified in other fields are confirmed. All three proposed hypotheses are confirmed, i.e. the relationship between after-sales service quality and customer satisfaction, the relationship between customer satisfaction and customer loyalty, and the relationship between after-sales service quality and customer loyalty, either directly and indirectly. This study provides practical implycations to landed housing management that they need to pay more attention to their after-sales service quality because good services generate satisfied and loyal customers. These loyal customers are more likely to make repeat purchase and provide a positive recommendation on their products/services.

There are some research limitations in this study. First, we were constrained to use convenience sampling technique because we did not have access to every resident of the four housing complexes. The second limitation is that not every middle-upper class landed housing in Surabaya was surveyed, for example, Pakuwon Indah housing complex in West Surabaya. Further research may consider to include cultural factors as mediating variables because cultural factors also affect consumer behavior (Solomon [24]). The other recommendation is to examine the moderating effect of residency duration on the relationship among after-sales service quality, customer satisfaction and customer loyalty. 


\section{References}

1. Rigopoulou, I. D., Chaniotakis, I. E., Lymperopoulos, C. and Siomkos, G. I., After-sales Service Quality as an Antecedent of Customer Satisfaction: The Case of Electronic Appliances. Managing Service Quality: An International Journal, 18, 2008, pp. 512-527.

2. Anderson, E. W. and Mittal, V., Strengthening the Satisfaction-profit Chain, Journal of Service Research, 3, 2000,pp. 107-120.

3. Yang, Z. and Peterson, R. T., Customer Perceived Value, Satisfaction, and Loyalty: The Role of Switching Costs. Psychology \& Marketing, 21, 2004, pp. 799-822.

4. Anderson, E. W., Fornell, C. and Lehmann, D. R., Customer Satisfaction, Market Share, and Profitability: Findings from Sweden. Journal of Marketing, 58, 1994, pp. 53-66.

5. Fazlzadeh, A., Bagherzadeh, F. and Mohamadi, P., How after-Sales Service Quality Dimensions Affect Customer Satisfaction, African Journal of Business Management, 5, 2011, pp. 7658-7664.

6. Saccani, N., Johansson, P. and Perona, M., Configuring the After-sales Service Supply Chain: A Multiple Case Study. International Journal of Production Economics, 110, 2007, pp. 52-69.

7. Lele, M. M., After-sales Service Necessary Evil or Strategic Opportunity? Managing Service Quality: An International Journal, 7, 1997, pp. 141145.

8. Parasuraman, A., Berry, L. L. and Zeithaml, V. A., Refinement and Reassessment of the Servqual Scale. Journal of Retailing, 67, 1991, pp. 420-450.

9. Fornell, C., Johnson, M. D., Anderson, E. W., Cha, J. and Bryant, B. E., The American Customer Satisfaction Index: Nature, Purpose, and Findings. Journal of Marketing, 60, 1996, pp. 718.

10. Gorondutse, A. H. and Hilman, H., Mediation Effect of Customer Satisfaction on the Relationships between Service Quality and Customer Loyalty in the Nigerian Foods and Beverages Industry: Sobel Test Approach. International Journal of Management Science and Engineering Management, 9, 2014, pp. 1-8.

11. Ndubisi, N. O. and Wah, C. K., Factorial and Discriminant Analyses of the Underpinnings of Relationship Marketing and Customer Satisfaction, International Journal of Bank Marketing, 23, 2005, pp. 542-557.
12. Khan, I., Impact of Customers Satisfaction and Customers Retention on Customer Loyalty. International Journal of Scientific \& Technology Research, 1, 2012, pp. 106-110.

13. Lin, H.-H. and Wang, Y.-S., An Examination of the Determinants of Customer Loyalty in Mobile Commerce Contexts. Information \& Management, 43, 2006, pp. 271-282.

14. Rauyruen, P., Miller, K. E. and Barrett, N. J., Relationship Quality as a Predictor of B2b Customer Loyalty. Journal of Business Research, 60, 2007, pp. 21-31.

15. Gremler, D. D. and Brown, S. W., Service Loyalty: Its Nature, Importance, and Implications. In: Edvardsson, B., Brown, S. W., Johnston, R. and Scheuing, E. E. (eds.) Advancing Service Quality: A Global Perspective. Jamaica, NY: International Service Quality Association, 1996.

16. Ahn, J. S. and Sohn, S. Y., Customer Pattern Search for after-Sales Service in Manufacturing. Expert Systems with Applications, 36, 2009, pp. 5371-5375.

17. Aktepe, A., Ersöz, S. and Toklu, B., Customer Satisfaction and Loyalty Analysis with Classification Algorithms and Structural Equation Modeling, Computers \& Industrial Engineering, 86, 2015, pp. 95-106.

18. Zeithaml, V. A., Berry, L. L. and Parasuraman, A., The Behavioral Consequences of Service Quality. Journal of Marketing, 60, 1996, pp. 31-46.

19. Hair, J. F., Jr., Black, W. C., Babin, B. J. and Anderson, R. E., Multivariate Data Analysis, Upper Saddle River, NJ, Pearson Prentice Hall, 2010.

20. Anderson, J. C. and Gerbing, D. W., Structural Equation Modeling in Practice: A Review and Recommended Two-Step Approach. Psychological Bulletin, 103, 1988, pp. 411-423.

21. Wang, T. and Ji, P. 2010. Understanding Customer Needs through Quantitative Analysis of Kano's Model. International Journal of Quality \& Reliability Management, 27, 2010, pp. 173-184.

22. Berry, L. L., Parasuraman, A., Zeithaml, V. A., Adsit, D., Hater, J., Vanetti, E. J. and Veale, D. J., Improving Service Quality in America: Lessons Learned. The Academy of Management Executive, 8, 1994, pp. 32-52.

23. Bodet, G., Customer Satisfaction and Loyalty in Service: Two Concepts, Four Constructs, Several Relationships, Journal of Retailing and Consumer Services, 15, 2008, pp. 156-162.

24. Solomon, M. R., Consumer Behavior: Buying, Having, and Being, Harlow, Essex, Pearson Education Limited, 2016. 